Article

\title{
Comparative Framework for Understanding Jewish and Christian Violent Fundamentalism
}

\author{
Arie Perliger \\ Department of Social Sciences, United States Military Academy, 607 Cullum Road, \\ Lincoln Hall, Rm. 120. West Point, NY 10996, USA; E-Mail: arie.perliger@usma.edu; \\ Tel.: +1-845-938-0412
}

Academic Editor: John L. Esposito

Received: 21 July 2015 / Accepted: 21 August 2015 / Published: 31 August 2015

\begin{abstract}
Although most scholars agree that in the last couple of decades, religious fundamentalism has become the dominant ideological feature in the landscape of modern terrorism, many prefer to ignore the fact that this is not a development which is restricted to the Islamic world, and that other religious traditions have also experienced growth in groups which prefer to use violent strategies to promote their sacred visions. The current chapter strives to fill this gap by analyzing the emergence of violent religious groups in two distinct, non-Islamic, religious traditions. At first glance, the Christian Identity and the Religious-Zionist movements have very little in common. However, both movements served as a breeding ground for the emergence of violent fundamentalist groups aspiring to facilitate an apocalyptic/redemption scenario by engaging in illegal violent campaigns. Moreover, in both cases, the role of spiritual leaders was crucial in shaping the radicalization of the groups and their target selection, and the violence had a clear symbolic narrative. In other words, for the members of these violent groups, the violence served a clear role in the mobilization of potential supporters, and the branding and dissemination of the movement's ideology. Finally, while in general, terrorism is perceived as the weapon of the weak, in these two cases it was perpetrated by individuals/groups affiliated to communities belonging to the dominant religious framework in their respective polities (i.e., the Religious-Zionist and Christian Identity movements are perceived by their members as branches of Judaism and Christianity). Hence, by utilizing a comparative framework, the article will not just analyze the violent manifestations that emerged from these two movements, but also try to identify the unique factors that characterize and facilitate the emergence of religious groups within religious communities belonging to the dominant religious tradition in their societies.
\end{abstract}


Keywords: terrorism; Christian Identity; Religious-Zionism; Israel; religious movements

\section{Introduction}

On the morning of Tuesday, 10 August 1999, the North Valley Jewish Community Center in Los Angeles was crowded with more than 250 playing children. A few minutes before $11 \mathrm{am}$, Buford Oniel Furrow parked a Chevrolet van that he had purchased a few days earlier, at the entrance to the Community Center. He proceeded into the lobby carrying an Israeli Uzi-type submachine-gun and started shooting at the crowd. When he left the building a few minutes later, three kids, a receptionist, and a camp counselor were lying wounded on the floor [1]. But these were not his last victims that day. A short time later, in the town of Chatsworth, he shot and killed Joseph Ileto, a USPS worker. Ileto had just delivered mail to a home and was returning to his postal truck when Furrow asked him to mail a letter for him and immediately after that, shot him with his Glock 9mm handgun [1]. Furrow eventually surrendered at the Las Vegas FBI office. During the investigation of the event, Furrow's association with the Aryan Nations and the Christian Identity movement at large was uncovered, as well as the fact that he had been motivated by racial sentiments, a core element of the movement's ideology.

Despite events such as the one described above, and the fact that the Christian Identity movement continues to proliferate (today including more than 70 active ministries in over 34 states, with approximately 50 thousand followers and/or members) ([2], p. 139), it has received little attention from contemporary students of political violence. Although most scholars agree that in the last couple of decades, religious fundamentalism ("Strict adherence to certain theological doctrines, in reaction against modernist theology" [3]) has become the dominant ideological feature in the landscape of modern terrorism [4-6], many prefer to ignore the fact that this is not a development which is restricted to the Islamic world, and that other religious traditions have also experienced growth in groups which prefer to use violent strategies to promote their sacred visions.

The current article strives to fill this gap by analyzing the emergence of violent religious groups in two distinct, non-Islamic, religious traditions. At first glance, the Christian Identity and the Religious-Zionist movements have very little in common. However, especially from the late 1970s and early 1980s, both movements served as a breeding ground for the emergence of violent fundamentalist groups aspiring to facilitate an apocalyptic/redemption scenario by engaging in illegal violent campaigns. Moreover, in both cases, the role of spiritual leaders was crucial in shaping the radicalization of the groups and their target selection, and the violence had a clear symbolic narrative. In other words, for the members of these violent groups, the violence served a clear role in the mobilization of potential supporters, and the branding and dissemination of the movement's ideology. Finally, while in general, terrorism is perceived as the weapon of the weak, in these two cases it was perpetrated by individuals/groups affiliated to communities belonging to the dominant religious framework in their respective polities (i.e., the Religious-Zionist and Christian Identity movement are perceived by their members as branches of Judaism and Christianity). Hence, by utilizing a comparative framework, the next sections will not just analyze the violent manifestations that emerged from these two movements, 
but also try to identify the unique factors that characterize and facilitate the emergence of religious groups within religious communities belonging to the dominant religious tradition in their societies.

\section{Ideology}

Before discussing the violent manifestations of the religious-Zionist and Christian Identity movements, a concise introduction to their ideological tenets will be presented, followed by an attempt to identify how their ideological structures facilitate violence by some members of these movements.

\subsection{Christian Identity Movement}

The ideology of the Christian Identity movement is rooted in the writings of a radical Irish weaver, John Wilson, who asserted in the mid-nineteenth century, that the lost biblical Israeli tribes migrated from Palestine and settled in northern Europe to become the Anglo-Saxon nations. Hence, he believed that since the Anglo-Saxons are the true chosen people, the "British Israelite" had a divine obligation to dominate the earth, in the spirit of the biblical prophecies given to the people of Israel [7]. These ideas were spread in the U.S. during the late nineteenth and early twentieth century via the British-Israelite World Federation, which had several branches on the East Coast. When William J. Cameron and Howard Rand gained dominancy over the movement before World War II, they identified the Zionist movement and Jews as the main adversaries of the British-Israelite movement; hence, they gradually embraced anti-Semitic and racial rhetoric. Cameron and Rand's followers, preachers such as Wesley Swift, Richard Butler, and William Porter Gale, continued to integrate similar theological analyses via their respective identity churches and groups (such as the Church of Jesus Christ Christian, and The US Christian Posse Association) and emphasized anti-Semitic notions, principles of white supremacy and racial segregation, as well as related apocalyptic visions [8-10].

Several core beliefs characterize the Christian Identity movement. First, Jews are the direct biological offspring of the devil or Satan, who are using various manipulations in order to gain dominancy in financial arenas all over the world as a tool for promoting the destruction and decomposition of Aryan civilizations. Thus, the Jews are not just the natural "threat" of the identity movement (because of their perception that they are the chosen people), but they aim to destroy or control other religious traditions ([8], pp. 34-39); [9,10]. The second core belief of the movement could be described as an apocalyptic perception that humanity is in its final days, hence, all believers should be ready for the second coming and the restoration of the dominancy of the true people of Israel. However, the movement emphasizes the active, rather than the passive, role of the believers. While many fundamentalist Protestants have asserted that during the time of the "rapture" and tribulation at the end of days and towards the second coming of the Messiah (times which will be characterized by violence, persecution and war), the "saved" will be taken from earth (hence, will not be directly involved in the struggle between forces of light and darkness), Identity scholars maintain that the true believers will embrace the opportunity to actively engage in the fight against the forces of evil. Therefore, believers will be fighting a war between the children of light and the children of darkness (Jews), which will end with divine intervention, and the establishment of Christ's Kingdom ([8], pp. 79-81). The third ideological pillar of the Identity movement is the support for racial segregation, which should be imposed to maintain the superiority of the Aryan race and to prevent racial mixing. These perceptions are an extension of the 
movement's unique interpretation of the biblical story of Genesis, in which Adam was not the first man, but the first white man. Before him (pre-Adamic), people of color were created by God, who had lesser qualities. The white people as well could be divided into superior and inferior "seed-lines": those who are descendants of Adam and Eve (Aryans), and all others (non-Aryans), who are descendants of Eve and the serpent (the reflection of the devil) ([8], pp. 162-63); [11]. Accordingly, Identity leaders asserted that race mixing was the original sin that led to the expulsion of the white man from the Garden of Eden. It should be noted that these kinds of distinctive interpretations of religious texts are not unique, as Identity leaders consistently produce interpretations of religious texts that can justify and rationalize the ideological pillars of the movement. While the relations between the various ideological components of the movement are complicated, from an analytical perspective, it is useful to see it as a religious movement, in which ethno-centric and racist attitudes are part of its theological pillars.

\subsection{Religious Zionist Community}

As in the case of the Identity movement, the foundational notions of Religious-Zionist ideology appeared first in the mid-nineteenth century, and gained momentum, becoming a mass movement, in the early twentieth century. The major gap between the Jewish Ultra-Orthodox (Haredi Jews) and the Religious-Zionists relates to their views regarding the circumstances that will lead to the foundation of Jewish religious kingdom in the Land of Israel. While the former believe that Jews should wait passively until the arrival of the Messiah, which will be followed by the establishment of a Jewish Kingdom, Religious Zionists preached a more active role. They too believed that a Jewish religious kingdom would be established following the arrival of the Messiah, but the founding fathers of the Religious-Zionist movement advocated that by settling the land of Israel, working the land, and restoring the Hebrew language, this redemption process could be expedited [12-14]. Thus, in contrast to the ultra-Orthodox, the Religious-Zionists have historically made efforts to find ways to bridge the gap between Jewish Orthodoxy and secular Zionist ideology. Moreover, in many ways, they accepted the dominancy of the secular Zionist streams, believing that the establishment of the State of Israel should be the end point of their efforts to expedite the redemption process. However, the implications of the war of 1967 changed this dynamic. Following the war, parts of the religious-Zionist community adopted beliefs which regarded the realization of the vision of the Greater Land of Israel by Jewish settlement in the West Bank as a decisive phase in the salvation of the People of Israel, and in the establishment of a religious Jewish state. In other words, they see the establishment of the State of Israel in 1948, the decisive Israeli victory of 1967 and the Israeli settlement of the West Bank, as stages in the redemption process [13,14]. As a consequence, any attempt to backtrack this process, for example by conceding lands to the Palestinians in the West Bank, is seen by them as a direct violation of God's will and should be prevented. Almost 50 years after the 1967 war, this vision has become dominant in the Religious-Zionist community, which comprises the decisive majority of the settler population and is today almost entirely ideologically homogenous [15].

Another important process has characterized the Religious-Zionist movement in the last couple of decades. After the establishment of the Israeli state, the movement was comfortable in taking a back seat, and accepting the dominancy of secular Zionism in the Israeli civilian and social spheres, while focusing on ensuring the prosperity of its own cultural and social infrastructures (schools, religious 
institutions, etc.). Since the early 1980s however, there has been a growing desire by the movement to have a more influential role in shaping the public and social sphere in Israel, and pushing its values to the mainstream. Hence, the community does not accept the liberal assumption that religion is a private matter [14,16], and that the collective does not have the right to impose religious practices on its members. Accordingly, the leaders of the Religious-Zionist movement seek to enforce their values not only within their own community, but on all Jews in Israel. Practical manifestations of their attitude can be seen in the aspirations of the movement to shape state legislation in the spirit of the Halacha (Jewish religious law), to impose religious components in secular schools' curriculum, and to prevent harm to the status of religion in the state's institutions and procedures (such as in the Israeli Defense Forces (IDF)), by any means [17]. As will be made clear later, violent manifestations of the movement aimed to both promote the movement's value system, as well as to prevent policies that were perceived as delaying or posing an obstacle to progress in the redemption process.

\subsection{Ideology-Comparative Analysis}

When analyzing the ideology of the two movements, and especially the way their ideological framework has been structured, several important similarities emerge, which can provide some initial ideas about how they became a breeding ground for violent actors.

The first is related to the avant-garde nature of the Identity and Religious-Zionist movements. While the supporters/members of both movements are a small minority within their respective societies, they see the implementation of their movement's vision as crucial for the survival of their entire respective nation/culture. Thus, the fact that members of these movements feel responsible for the "well-being" of their entire nation may push them to act via radical means to insure the promotion of policies that are necessary for the implementation of their movement's goals. Moreover, both movements see themselves as a transformative avant-garde, responsible to promote social/cultural transformation of mainstream culture by advocating their norms and morals. In this regard, during the past 40-50 years, there have been times in which there were indications that (at least in the public sphere) the respective American and Israeli societies are moving further away from the movements' belief system and core principles. That may explain the escalation of some elements within these movements to illegal and violent practices, as movement members feel that radical means must be exercised to overturn what they see as the societal moral decline. To illustrate, In Israel, especially during the 1990s, polls consistently showed that the majority of the public is supportive of the two state solution, and willing to make territorial compromises in the West Bank [18]. In the U.S., ideas of racial segregation, white supremacy and de-legitimization of non-Christian communities are increasingly perceived as illegitimate in the mainstream public sphere, probably more than at any time in the past.

Another characteristic that is shared by both movements is a flat and a pluralistic power structure, which provides flexibility in the interpretation of the movements' religious texts and core principles. In other words, the movements are comprised of a relatively high number of spiritual leaders, each promoting and disseminating his own interpretation of the movement's core religious texts to his group of followers ([2], pp. 31-36). While some of these spiritual leaders are more influential than others, there is no strong mechanism that enables enforcement of consensus within the movements. This structure lends itself to internal competition between the various "chapters" of the movements, and may encourage 
some leaders to adopt extreme interpretations of the texts, so to distinguish themselves from other leaders, and to appeal to more activist constituencies. It is therefore understandable how some segments may slide into illegal and violent activities when the movement's values seem to be threatened by external actors or are ignored by mainstream society. Simply put, members of the movements who are interested in engaging in extreme activities in order to "protect" movement values and way of life, can usually find at least some leaders who provide interpretations that may justify such acts. It is not a coincidence, for example, that the founders of The Order, the most well organized violent framework that emerged from the Identity movement, were members of Richard Butler's Aryan Nations Church of Jesus Christ Christian (mostly known just as Aryan Nations or $A N$ ) which for years pushed its members both to cooperate with other actors within the violent far right landscape (Neo-Nazis, KKK to name a few) and promoted ideas which presented the federal authorities as the ultimate representative of the dark forces. As the words of Pastor August Kreis (the current formal leader of $A N$ ) illustrate- "We, as you elect, will carry out your wrath against your enemies (Satan's forces and anti-Christ) in this, the great battlefield, called earth...We look forward to the destruction of your enemies on this earth and to the establishment of your kingdom" [19].

Within the Religious-Zionist movement we can find similar dynamics. Before its first attack in 1980 (in retaliation for the killing of a Jewish student in Hebron), members of the most well organized violent group to emerge from the Religious-Zionist movement, the Jewish Underground, approached at least two spiritual leaders, whom they felt would be able to provide moral support to their actions. Indeed, both leaders were willing to support some kind of retaliation attack ([12], p. 51).

Lastly, it is important to note that both movements endorse the view that they play a role in a progressive historical process that will end with an apocalyptic event, leading to the realization of their vision. Hence, in both we see strong emphasis on the active role of the individual believer. Each member of the community is responsible via his personal behavior and actions for promoting and maintaining the historical process and the vision to which the movement aspires. This empowering environment, which encourages individual activism, entrepreneurship, and responsibility, also provides a space of legitimacy for those interested in engaging in more extreme activities. To illustrate, during the implementation of the Oslo process, as well as during the implementation of the Israeli "Disengagement Plan" from the Gaza Strip, various leaders within the Religious-Zionist movement called for IDF soldiers who were religious Zionists to refuse to participate in any military activity that directly or indirectly assisted the evacuation of Jewish settlements in the West Bank or the Gaza Strip, emphasizing that every individual had to do whatever he could to support the ideological tenets of the movement [20]. Similar emphasis can be found in one of the most popular and well-known publications of the $A N$, which is basically a story of individual empowerment. The "Turner Diaries" which was initially published in serial form by the $A N$ 's "Attack" magazine, and in 1978 as a book, tells the story of Earl Turner, who joins a revolutionary group which fights against the growing racial integration and gun control legislation by engaging in insurgency warfare against the authorities, including radical violent attacks against symbols of the federal government. Interestingly, the book, which was published 23 years before 9/11 attacks, ends with Turner crashing his airplane into the Pentagon [21].

Who were the people and groups who actually translated this mind set of empowerment into a campaign of violence? The following section will examine them and analyze the similarities in the operational dimensions of the violent manifestations of the movements. 


\section{Violent Manifestations}

Before discussing the violence that was perpetrated by members of the Christian Identity and the Religious-Zionist movements, it is important to note, that in both cases we are dealing with a small minority. The majority of the members and leaders of these movements did not participate in or endorse violence. This partially explains the fairly limited violence that was committed by the two movements, and its infrequent nature.

\subsection{The Violent Aspects of the Christian Identity Movement}

Probably the first violent group which emerged from the Identity movement was the above mentioned The Order. Founded in 1983 by an Identity activist by the name of Robert Matthews, it aimed to engage in guerrilla warfare against the federal government (or what members of the group referred to as ZOG-Zionist Occupation Government), hoping to ignite a mass uprising [22]. Comprised mostly of AN members, The Order initiated a campaign of counterfeiting, armed robberies and violent attacks between 1983 and 1986. Among the group's violent attacks, worth mentioning are the robbery of a Brinks armored vehicle near Ukiah, California, which netted $\$ 3.8$ million, the assassination of Alan Berg, a Jewish liberal radio host at KOA radio, the bombing of a pornographic theater in Seattle, Washington and of a synagogue in Boise, Idaho in April 1984 [22]. The limited operational experience of the group's members, probably explains the FBI's quick success in penetrating the group and detaining most of its members in less than a year after its initial attacks.

The quick elimination of The Order probably had some deterrent effect, since only in the early 1990s was it possible to identify the resurfacing of violent acts by members of Identity groups. Most perpetrators came from four specific groups: Aryan Republican Army, Creativity Movement/World Church of the Creator (also known as WCOTC), Phineas Priests, and AN. While the Aryan Republican Army was engaged in a systematic campaign of robberies between 1994 and 1995, attacks by members of the three other groups were mainly spontaneous, opportunity based, by lone wolves or small groups ([2], p. 79). Examples are the shooting attacks by Benjamin Smith, member of WCOTC who, during the weekend of July 4, 1999, filled his Ford Taurus with guns and ammunition and during a three-day, two-state shooting spree killed two people and wounded nine others [23]; or the attacks perpetrated by Jules Fettu, a member of Phineas Priests, who, fully armed with two guns and a pipe bomb, attacked a youth service at the Wedgwood Baptist Church and killed seven people, while shouting anti-religious statements [24]. This wave of attacks continued until the early 2000s before declining significantly in the last decade.

To conclude, attacks by Identity group members focused on minorities and financial institutions. The former were naturally linked to the movement's ideological tenets. The second were explained by members of The Order and Aryan Republican Army, as a necessity for funding of the groups' recruitment activities and future operations.

\subsection{The Violent Aspects of the Religious Zionist Movement}

As pointed out by Perliger and Pedahzur [15], most of the violence that was produced by members of the Religious-Zionist movement was in response to two types of pressure: (a) an escalation in the 
security situation in the West Bank, and especially an increase in Palestinian violence against the settler population (i.e., the first and the second Palestinian uprisings, also known as Intifadas); (b) peace initiatives which might potentially lead to Israeli territorial concessions. In both cases the settlers' leaders were concerned that the violence/peace processes, would pressure Israel to make territorial concessions to the Palestinians, hence diverting Israel from the path of implementing its sovereignty over the "Greater Land of Israel", which is a core element of the Religious-Zionist theology, as explained above.

Several specific examples can illustrate the dynamics mentioned above. In the early 1980s, the combination of Israeli agreement (via the Camp David accords) to provide autonomy to the Palestinian population in the West Bank, and an increase in Palestinian violence, led to the emergence of groups such as the Jewish Underground and the Lifta Gang, which by attempting to bomb and destroy the Al-Aqsa Mosque on the Temple Mount, hoped to promote regional instability that would halt the peace process between Israel and Egypt ([12], pp. 51-52, 141-43). Similarly, the emergence of the Bat-Ayin group, which was engaged in a violent campaign of ambushing Palestinian vehicles and which was eventually exposed after a failed attempt to place an improvised bomb at the entrance to a Palestinian school, is attributed to the outbreak of the second Palestinian uprising [15]. Lastly, the assassination of Prime Minister Itzhak Rabin in 1995, by Yigal Amir (who had his own supporting network), was a direct result of Rabin's attempt to push forward the Oslo Peace process, and his willingness to promote territorial concessions ([12], pp. 101-10).

The examples above also illustrate the two major targets that were preferred by violent groups affiliated with the Religious-Zionist community. The first, and by far the most popular, is the Palestinian population in the West Bank, as their residence in the West Bank and their struggle for political independence were perceived as the most acute threat to the implementation of the vision of the Greater Land of Israel. Moreover, the first and second Palestinian uprisings, also positioned the Palestinian population as a direct security threat in the eyes of the settlers. Lastly, the religious symbols used by the Palestinian population to legitimize their political demands for Palestinian independence, such as the Dome of the Rock or Al-Aqsa Mosque, were perceived as an abomination and a direct obstacle to progress towards redemption in the eyes of many leaders of the Religious-Zionist movement. The second preferred target was Jewish leaders and/or public figures, who were known to be supporters of the peace process. The most notable examples are the above mentioned assassination of Prime Minister Rabin and the attempted assassination of Prof. Zeev Sternhell, a well-known Israeli academic and one of the most furious critics of the settlement movement, by Jacob Title, a resident of the Shvut Rachel settlement, who was also responsible for killing two Palestinians, on other occasions [25].

\subsection{Radicalization and Violence-Comparative Analysis}

When looking into the operational characteristics of the violence that was perpetrated by groups affiliated with the Religious-Zionist and Identity movements, several interesting similarities can be detected. To begin with, in both cases the majority of the attacks were directed against specific ethnic/religious groups, the "absolute" outsiders in the eyes of movement members, while a minority of the attacks was aimed at what can be termed "internal" dissents. This reflects the fact that in both cases, specific external communities/outsiders are portrayed as the foremost threat to the ability of the movement to realize its vision, and to maintain its way of life. The de-legitimization, and sometimes, 
de-humanization, of these external communities, seems to help the more radical members of the movements to cross the psychological threshold that prevents most members from engaging in violent activism. In other words, the selective nature of the targets helps the perpetrators to legitimize their actions more effectively, as they can draw a direct association between their actions and the movement's ideological framework.

In addition, the violent acts provided an opportunity for these movements to shape the discourse related to their objectives/ideological agenda. Terrorism is a method of symbolic violence, in which groups try to overcome the gap in resources (between them and the polity) by utilizing violence which they hope will shape the political perceptions and attitudes of the public and/or policy makers. In the cases of the movements discussed in this article, the careful selection of targets seems to demonstrate the understanding of the perpetrators of the importance of utilizing the various components of the violent acts in order to crystalize a clear ideological massage, which will both facilitate recruitment, but also enhance in-group cohesion and solidarity.

Another similarity is related to the structure and the radicalization of the violent groups. While the classical literature on terrorism tends to portray a clear linkage between the emergence of a terrorist group and the emergence of a social or political deprivation [26], reversed dynamics can be perceived in the movements at the center of this discussion, as in many cases the networks existed before the decision to resort to violence. To begin with, unlike other ideological movements, a significant number of the Religious-Zionists, as well as members of the Identity movement, reside and spend time together in isolated spaces, where they are consistently exposed to a single ideological perspective, and can easily share and interact (just) with people who have similar views. As Perliger and Pedahzur [15] demonstrated, most members of the Religious-Zionist violent groups resided in ideological settlements in the West Bank. In the same manner, most of the more radical members of the identity movement spend time in compounds such as the one which was established by Richard Butler, $A N$ 's founder, near Hayden Lake, Idaho. On the one hand, these isolated environments facilitated effective indoctrination and commitment, and allowed effective control over members of the movement; on the other hand, prolonged ideological exposure, combined with strong peer interaction and positive feedback, may facilitate extremist interpretation of the movement's ideology, and a mindset which demands personal sacrifice for the group via violent activities. These circumstances can also explain why most of the groups are based on preexisting social networks, which existed before their members resorted to violence. Hence, in many cases the attacks were a more spontaneous response to perceived threats/hostilities against the community, opportunity based, perpetrated by social networks in which none of the members was what we can describe as a "professional" or "career" terrorist.

The fact that these groups were not comprised of "career" terrorists, may also explain their limited durability and "productivity". Many of these groups/perpetrators can be described as "one hit wonders", who were caught shortly after their "inaugural" attack, and failed to construct any organizational infrastructure that would enable a long term campaign. Even groups such as the Jewish Underground, which was active for several years, perpetrated just two attacks, and was involved in the planning of two additional operations (which eventually did not materialize). Groups who conducted double digit attacks (Bat-Ayin or Aryan Republican Army) were usually apprehended in a couple of years; far different from many of the left wing and Islamic groups that have populated the terrorism landscape in the last few decades, and which have been able to construct a durable operational infrastructure. 
Finally, it seems that in both cases, the violent campaigns did not just fail to promote the ideological objectives of the movements, but in many ways undermined their efforts to gain legitimacy. This does not mean that both movements failed to promote their political agendas. Actually, the opposite is true in the case of the Religious-Zionist movement. The following section will further elaborate on the movements' political effectiveness.

\section{Political Effectiveness}

How did the violence described above affect the ability of the Identity and Religious-Zionist movements to promote their ideological framework, to gain political influence, and to mobilize support? The current section will try to answer these questions while attempting to explain the significant gap between the two movements in terms of their political capital. Or in other words, why did the violent manifestations of the Identity movement further enhance its marginal status, while the violent manifestations of the Religious-Zionist movement did not prevent it from continuing to expand its political influence within the Israeli political system, and ensure the ongoing support of the Israeli authorities in the settlement project in the West Bank.

\subsection{The Political Irrelevancy of the Identity Movement}

The Identity movement has always held a marginal status within American society. Unlike some of the other far right movements, such as the Skinheads in the 1990s, or the KKK in the 1920s and later in the 1950s, it was never able to develop a mass following and construct an effective nationwide organization. Moreover, since its ideological transformation in the 1920s and 1930s, which included the gradual integration of anti-Semitic notions and practices, and more focus on sentiments of white supremacy, the movement was also increasingly associated with other controversial elements within the far right landscape, a process which further undermined the movement's ability to mobilize mass support.

The cooperation between the Identity movement and other far-right movements could be traced to the appearance of the first "modern" Christian Identity groups/churches on the West Coast in the late 1940s. A series of conventions that were organized in the early and mid-1940s in the North Pacific by a British-Israelite association from Vancouver led to the formation of a network of groups on the Pacific coast that departed from the traditional British-Israelite ideological tradition, emphasizing racial conspiracy theories and apocalyptic visions ([2], p. 74). The most well-known of these is probably Wesley Swift's The Church of Jesus Christ Christian, founded in 1948 in Lancaster, California, which, under the charismatic leadership of Swift, became the center of the movement. Swift's anti-Semitic rhetoric left no doubt that the movement was ideologically in line with the other white supremacy groups in America, as exemplified by a statement he made in the early 1950s in one of his lectures: "All Jews must be destroyed. I prophesy that before November 1953 there will not be a Jew in the United States, and by that I mean a Jew that will be able to walk or talk" [27].

In the 1980s and 1990s the ideological similarities eventually led to direct cooperation between the Identity movement and other white supremacy groups, especially via the attempts of Richard Butler, $A N$ 's founder, to transform the group's compound into "The International Headquarters of the White Race" [19]. Indeed, in the 1990s the $A N$ 's compound became a safe haven for leaders of various white 
supremacy groups. It was isolated and remote enough to discourage the interference of law enforcement and the media, but at the same time provided the ambience of the outdoors, wild freedom, and intellectual stimulation. Hence, some of the more known ideologues of the American far right, figures such as KKK's Louis Beam, WAR's Tom Metzger, and even the founder of the Montana Militia Jon Trochman, felt comfortable to utilize the compound in order to operate and further develop their ideological visions, to forge ties to improve coordination and cooperation, and to mobilize new recruits ([2], p. 77).

From a political perspective, the transition of the Identity movement from a religious group with a specific interpretation of biblical texts regarding the identity of the chosen Hebrew people, into another stream of the American white-supremacy community, meant that the movement had limited capabilities to develop any meaningful political power, as white supremacy notions, especially in the religious context, were never even close to being perceived as legitimate by any meaningful part of the American electorate or mainstream political leadership (the ongoing failure of the former KKK leaders to be elected to political offices is a case in point). The violent manifestations of some Identity groups naturally positioned the movement, even further to the right in the eyes of the public and policy makers, in the same category of groups such as the KKK, the American Nazi Party, and the Hammeskins Nation.

Another aspect which probably undermined the Identity movement's ability to develop political influence is its focus on "localism". Losing hope that they could operate via the legitimate political channels, the $A N$ promoted the idea of creating a network of Aryan farm communities, which would be run according to the local "Biblical/Aryan" laws, independent of federal authorities ([8], pp. 231-32). Whether this vision was driven by hostility towards the authorities or by the desire to promote racial segregation, it represented a clear dissent from the mainstream political arena.

To conclude, despite the rise in the last few years of more moderate versions of the old Identity groups, and the fact that some of them were able to use modern technology to expand their mobilization efforts (Pete Peters' La Porta Church of Christ is a case in point) there is no indication that the movement has been able to amass any significant political capital.

\subsection{The Political Success of the Religious-Zionist Movement}

In contrast to the Identity movement, the Religious-Zionist movement was able to develop powerful political mechanisms in the last 40 years, which enable it, in the eyes of many, to effectively manipulate the Israeli political system, despite never gaining more than $10 \%-15 \%$ of the seats in the Israeli parliament or in the executive branch. This success is manifested mainly via its ability to expand the settlement project in the West Bank-including at times when Israeli left-wing parties dominated the executive branch - despite it being a disputed issue within the Israeli political system and society.

Several factors contributed to the political effectiveness of the Religious-Zionist movement. To begin with, acknowledging that the majority of the secular Israeli public would not be willing to support Israel's control over the West Bank based on the Religious-Zionist narrative of the redemption process, the movement adopted a complementary narrative which focused on the need to maintain Israeli control over the West Bank for security reasons, and that the settlements themselves are an important tool for enhancing Israel's security. Hence, the rhetoric of many (political) Religious-Zionist leaders, while emphasizing the historical/religious right of the Jewish people to the land of Israel, has also traditionally focused on the importance of maintaining control of the West Bank from a national security angle 
(providing Israel with greater strategic depth). They have also concentrated on the role of the settlements as a buffer zone between Palestinian terrorism and the Israeli population (a belief that was shared by some within the security establishment) [28], and the risks the settlers have been taking in order to serve national goals [28]. The effectiveness of this rhetoric is illustrated by the ability of the Religious-Zionists to garner significant support from the Israeli secular electorate and secular parties for maintaining some Israeli control over parts of the West Bank [28].

The religious Zionist leaders have also been highly effective in developing symbolic rhetoric based on the traditional and popular Zionists terminology and legacy. More specifically, they tend to portray the settlers as true pioneers, who are willing to undergo significant hardships and costs, for the sake of the Jewish nation. This romantic image can easily parallel the common image of Zionist pioneers who arrived in Palestine in the late nineteenth and early twentieth centuries and founded most of the modern Zionist (Israeli) political movements/parties [14]. Hence, the Religious-Zionist leaders were also able to legitimize the settlements in the West Bank by presenting them as a continuation of the Zionist project at large, and in line with the traditional methods used by the founding fathers of the state to promote Jewish sovereignty.

Another factor that contributed to the success of the Religious-Zionist movement was its ability to build effective networks of influence within the Israeli governmental bureaucracy and political institutions, especially in organizations which were essential for the survival and expansion of the settlement project. Pedahzur [28] has effectively illustrated how the "political networks" of the Religious-Zionist movement within the Israeli military (via the NAHAL_Fighting Pioneer Youth), in relevant ministries (Defense, Housing, Tourism, Industry) and in semi-governmental organizations (which were the executive pillar of the Zionist movement prior to the establishment of the state, i.e., Jewish Agency) among others, allowed them to manipulate policy decisions and to create comfortable conditions for continuing expansion of the settlement project. As such, they were able not just to overcome the problem of having limited electoral power, but also to efficiently undermine policy decisions that were counterproductive to their ideological objectives [28].

The leaders of the Religious-Zionist community developed complex strategies to deal with the occasional manifestation of violence by members of the community and in order to ensure that these would not harm the movement's political brand. In general, most of the Religious-Zionist leaders have publicly rejected the use of violence (at least not through the legitimate state apparatuses). In most cases, they have been successful in creating a separation (in public opinion) between the perpetrators and the Religious-Zionist community at large. Moreover, in many cases, the movement has been able to portray the perpetrators as negative elements, operating on the margins of the community, suffering from mental illnesses, and/or suffering from the significant pressure of the security situation in the West Bank. Furthermore, the flat structure of the movement has allowed linking the occasional perpetrator with a specific, extreme segments, of the movement, and thus avoiding significant harm to the movement's image at large. A related factor, which has also probably mitigated the impact of violent manifestations on the legitimacy of the movement in the eyes of the Israeli public, has been the growing dominancy of hawkish views among the Israeli public. When a growing number of Israelis feel that a peace process/territorial concessions are not a viable option, that the conflict is escalating, and that the situation in the Middle East in general demands more aggressive security policies on the part of Israel, a potential by-product is more tolerance towards acts of violence against Palestinians. Lastly, in the last couple of 
decades, the Religious-Zionist movement has made a concentrated effort to increase its influence/presence within the IDF and the Israeli media. As for the former, today many of the IDF's elite units are dominated by Religious-Zionist youth. Emphasizing this direct contribution of the movement to the nation's security allows the movement leaders to counter the perception that views the movement as a threat to Israel's democratic nature or security. As for the latter, it has allowed the movement more effectively to socialize its norms and practices, and presents them as part of the new Israeli identity. In both cases, it has enabled the movement to further distance itself from a more militant image.

\section{Concluding Remarks}

In the last couple of decades, a growing number of religious streams preferred to manifest their departure from the mainstream of their religious tradition via violent campaigns. However, so far the investigations of these dynamics focused on the Islamic realm, or on religious streams that were associated with ethnic or religious minorities. By looking specifically at the Christian Identity and the Religious-Zionist movements, both relatively unknown, I have tried to provide some initial ideas to explain how structural and contextual factors may facilitate the emergence of violent segments within religious movements, which are not part of a minority segment of society.

Several conclusions can be drawn based on the analysis above. First, while political violence has been a feature of both movements, their distinct reaction to these manifestations of violence has had an impact on the long-term success of the movements. Moreover, while the ideological tenets of the contemporary Identity movement cannot coincide with democratic values, the Religious-Zionist movement has always emphasized its willingness to operate within the confines of the Israeli democratic framework, even though its long-term objective was not compatible with the idea of a Jewish democracy. Hence, despite the movements' lack of success in mitigating the emergence of violent elements from within, the general public in both societies has reflected differently on these acts of violence, marginalizing one movement (Christian Identity), while willingly accepting the legitimacy of the other (Religious-Zionists). Second, the analysis emphasizes the important role of social enclaves and the physical isolation of the members of the movements from mainstream society, as facilitators of radicalization. It seems that in both movements, the social networks that eventually slide into violence emerged from isolated spaces, with limited exposure to alternative interpretations of social and political reality. Hence, state policies that promote social integration may be part of the solution to counter radicalization within such movements. Third, the majority of the perpetrators of the violence were not "professional" terrorists; this is a partial explanation for the limited effectiveness of the attacks of members of the movements. Nonetheless, as relevant military technology and knowledge become more accessible than in the 1980s and 1990s, we cannot assume that future attacks will not be more effective. Fourth, some correlation exists between the organizational structure of the movements and the type of violence they produce. The flat and cellular structure of these movements, as well as the lack of formal ideological consensus, provides small social networks or individuals, space to identify potential rationalization and justification for militant activism. At the same time, the fragmentation of the movement also prevents, or makes it more difficult, to create a more long-term infrastructure for a violent campaign. Fifth, the focus of the violence on "illegitimate" outsiders helps the perpetrators to portray their acts as a self-defense, aimed at protecting the movement from external threats, as well as limiting the amount of internal criticism. It is no coincidence that many 
of the attacks were in what can be described as the first point of contact between members of the movements and "outsiders". Finally, it is interesting, and somewhat surprising, to note that the level of success of the movements in influencing mainstream society, and state policies, had no direct impact on the level of violence they produced. Hence, while perceived external threats to the well-being of the movement, may push some members to act violently, the level of success of the movement in garnering political capital, had limited impact on the decision whether to use violence or not, at least from initial review of the violence that was produced by both movements.

As for the future of the movements' violent bursts, cautious optimism is in place. As mentioned above, there are signs that the violence produced by members of the Identity movement is in decline. It seems that as long as future Israeli territorial concessions will be a remote possibility, the incentive for organized violence by members of the Religious-Zionist movement will be limited.

\section{Conflicts of Interest}

The author declares no conflict of interest.

\section{References}

1. Frank Gibney, Jr. "The Kids Got in the Way.” Time Magazine, 23 August 1999. Available online: http://content.time.com/time/magazine/article/0,9171,991784,00.html (accessed on 20 July 2015).

2. Arie Perliger. Challengers from the Sidelines: Understanding America's Violent Far-Right. New York: Combating Terrorism Center at West Point, 2013.

3. George M. Marsden. Fundamentalism and American Culture. New York: Oxford University Press, 1980, pp. 4-5.

4. Walter Laqueur. The New Terrorism: Fanaticism and the Arms of Mass Destruction. New York: Oxford University Press, 1999.

5. Andrew Tian Huat Tan, and Kumar Ramakrishna. The New Terrorism: Anatomy, Trends, and Counter-Strategies. Singapore: Eastern Universities Press, 2002.

6. Thomas R. Mockaitis. The "New" Terrorism: Myths and Reality. Westport: Praeger Security International, 2007.

7. John Wilson. "British Isealism: The Ideological Restraints on Sect Organization." In Patterns of Sectarianism: Organization and Ideology in Social and Religious Movements. Edited by Bryan R. Wilson. London: Heinemann, 1967.

8. Michael Barkun. Religion and the Racist Right. Chapel Hill and London: The University of North Carolina Press, 1994.

9. David A. Gerber. "Anti-Semitism and Jewish-Gentile Relations in American Historiography and the American Past." In Anti-Semitism in American History. Edited by David A. Gerber. Urbana: University of Illinois Press, 1986, pp. 20-22.

10. See unknown author. "Gentile Fall Involved in Hope of Jewish Rule.” Dearborn Independent, 1920, pp. 8-9.

11. Charles Roberts. Race over Grace: The Racialist Religion of the Christian Identity Movement. Lincoln: iUniverse, 2003, pp. 31-37. 
12. Ami Pedahzur, and Arie Perliger. Jewish terrorism in Israel. New York: Columbia University Press, 2009.

13. Zvi Rannan. Gush Emunim. Tel-Aviv: Hakibutz Hameuhad, 1980.

14. Baruch Zisser, and Asher Coen. From Reconciliation to Escalation. The Religious-Secular Division at the Start of the 21st Century. Jerusalem: Schoken, 2003.

15. Arie Perliger, and Ami Pedahzur. "Counter Cultures, Group Dynamics and Religious Terrorism." Political Studies, 10 December 2014. Available online: http://onlinelibrary.wiley.com/doi/10.1111/ 1467-9248.12182/abstract (accessed on 25 August 2015).

16. Ricky Tessler. "Religious Radicalism between/in the Defensive Democracy, Defensive Politics and Defensive Citizenship." State and Society 1 (2003): 585-619.

17. Eli Don Yehiye. The Politics of the Arrangement: Settling Disputes in the Realm of Religion in Israel. Jerusalem: Floersheimer Institute for Policy Studies, 1997.

18. Nir Hasson. "Despite It All, Most Israelis Still Support the Two-State Solution.” Haaretz, 7 July 2014. Available online: http:/www.haaretz.com/news/diplomacy-defense/israel-peace-conference/ 1.601996 (accessed on 25 August 2015).

19. Chester L. Quarles. Christian Identity : The Aryan American Bloodline Religion. Jefferson: McFarland, 2004, pp. 133-34.

20. Uri Glickman. "Rebelion of the Rabbis." NRG News, 4 July 2005. Available online: http://www.nrg.co.il/online/1/ART/918/613.html (accessed on 25 August 2015).

21. Andrew Macdonald. "The Turner Diaries." 1978. Available online: http://www.jrbooksonline. com/PDF_Books/TurnerDiaries.pdf (accessed on 25 August 2015).

22. Betty A. Dobratz, and Stephany Shanks-Meile. "White Power, White Pride!": The White Separatist Movement in the United States. New York: Twayne Publishers, 1997, pp. 36, 192.

23. Kirsten Scharnberg, Evan Osnos, and David Mendell. "The Making Of A Racist." Chicago Tribune, 25 July 1999. Available online: http://articles.chicagotribune.com/1999-07-25/news/9907250249_ 1_hale-supremacist-young-man (accessed on 25 August 2015).

24. Stephen E. Atkins. Encyclopedia of Right-Wing Extremism In Modern American History. Santa Barbara: ABC-CLIO, 2011, p. 55.

25. Efrat Wiess. "Jerusalem: Professor Ze'ev Sternhell Lightly Wounded by Pipe Bomb." Ynet News, 2008. Available online: http://www.ynetnews.com/articles/0,7340,L-3601841,00.html (accessed on 25 August 2015).

26. Martha Crenshaw. "The Causes of Terrorism." Comparative Politics 13 (1981): 379-99.

27. Daniel Levitas. The Terrorist Next Door, the Militia Movement and the Radical Right. New York: St. Martin's press, 2003, p. 25.

28. Ami Pedahzur. The Triumph of Israel's Radical Right. Oxford: Oxford University Press, 2012, p. 71.

(C) 2015 by the author; licensee MDPI, Basel, Switzerland. This article is an open access article distributed under the terms and conditions of the Creative Commons Attribution license (http://creativecommons.org/licenses/by/4.0/). 